\title{
İnfertilite ile İlgili Hemşirelik Alanında Yürütülen Lisansüstü Tezler
}

\section{Postgraduate Theses in Nursing Related to Infertility}

\author{
Nurcan Kirca ${ }^{1}$ (iD) Meryem Öngen ${ }^{1}$ (iD \\ ${ }^{1}$ Akdeniz Üniversitesi Hemşirelik Fakültesi, Doğum ve Kadın Hastalıkları Hemşireliği, Antalya, TÜRKIYE \\ Geliş tarihi/ Date of receipt: 26/06/2020 Kabul tarihi/ Date of acceptance: 31/01/2021 \\ c) Ordu University Faculty of Health Sciences, Department of Nursing, Turkey, Published online: 20/04/2021
}

öz

Amaç: Bu tanımlayıcı çalışmanın amacı, 2000-2019 yılları arasında infertilite ile ilgili yapılmış hemşirelik lisansüstü tezlerinin içeriklerini değerlendirmektir.

Yöntem: Bu çalş̧ma, retrospektif tanımlayıcı tipte bir araştırma olarak yapılmıştır. Çalışmaya 2000-2019 yılları arasında infertilite alanında yapılmış 56 adet hemşirelik lisansüstü tezi dâhil edilmiştir.

Bulgular: İnfertilite alanında yapılmış lisansüstü hemşirelik tezlerinin, \%78.6's1 yüksek lisans, \%21.4'ü doktora tezidir. Hemşirelik yüksek lisans tezlerinin \%95.4'ü ve doktora tezlerinin ise \%91.7'si Doğum ve Kadın Hastalıkları Hemşireliği alanında yapılmıștır. Yüksek lisans tezlerinin \%54.5'i 2015-2019 yılları arasında, doktora tezlerinin ise \%58.3’ü 2010-2014 yılları arasında yapılmıştır. İnfertilite alanında yapılmış hemşirelik yüksek lisans tezlerinin; \%29.5'i bilimsel bir dergide yayınlanmış ve \%6.8'i kongrede sunulmuştur. Doktora tezlerinin ise \%83.3'ü yayına dönüştürülmüştür. Yüksek lisans tezlerinin $\% 2.3$ 'ünü hemşirelerin yaşadığı güçlükler, \%2.3'ünü mesleki roller/tutumlar/görüşler ve \%95.4'ünü hasta merkezli çalışmalar oluştururken, doktora tezlerinin ise tamamıı hasta merkezli çalışmalar oluşturmaktadır. Hemşirelik yüksek lisans tezlerinin \%84.1'inde ve doktora tezlerinin \%58.3'ünde ölçek kullanılmıştır.

Sonuç: İnfertilite alanında sınırlı sayıda hemşirelik lisansüstü tez çalışmasına ulaşıııștır. Ayrıca bu tezlerin çok az bir kısmı akademik yayına dönüştürülmüştür. İnfertilite hemşireliği alanında hemşirelik bakımının ve infertilite hemşirelerinin rollerinin ön planda olduğu daha çok lisansüstü tez çalışmasına ihtiyaç duyulmaktadır.

Anahtar kelimeler: Hemşirelik, infertilite, tez çalışması, lisansüstü

\section{ABSTRACT}

Objective: The aim of this descriptive study is to evaluate the content of the nursing postgraduate theses on infertility between 2000 2019.

Method: This study was conducted as a retrospective descriptive study. 56 graduate nursing theses in the field of infertility between 2000 and 2019 were included in the study.

Results: Of the postgraduate nursing theses made in the field of infertility, $78.6 \%$ is master's thesis, $21.4 \%$ is doctoral thesis. $95.4 \%$ of nursing master theses and $91.7 \%$ of doctoral theses have been done in the field of Obstetrics and Gynecology Nursing. 54.5\% of master's theses were done between 2015-2019, and 58.3\% of doctoral theses were done between 2010-2014. Nursing master theses in the field of infertility; $29.5 \%$ was published in a scientific journal and $6.8 \%$ was presented at the congress. $83.3 \%$ of doctoral theses have been translated into publication. While $2.3 \%$ of master's theses consist of difficulties experienced by nurses, $2.3 \%$ are professional roles/attitudes/opinions and $95.4 \%$ are patient-centered studies, all doctoral dissertations are patient-centered studies. The scale was used in $84.1 \%$ of nursing master theses and $58.3 \%$ of doctoral theses.

Conclusion: A limited number of nursing postgraduate thesis studies in the field of infertility have been reached. In addition, few of thesis have been converted into academic publications. In the field of infertility nursing, there is a need for more postgraduate thesis studies where nursing care and the roles of infertility nurses are at the forefront.

Keywords: Nursing, infertility, thesis, postgraduate

ORCID IDs of the authors: NK: 0000-0003-1856-4026, MÖ: 0000-0001-8708-3336

Sorumlu yazar/Corresponding author: Arş. Gör. Meryem Öngen

Akdeniz Üniversitesi Hemșirelik Fakültesi, Doğum ve Kadın Hastalıkları Hemşireliği, Antalya, TÜRKIYE

e-posta/e-mail: ongenmeryem@gmail.com

Atıf/Citation: Kırca N, Öngen M. (2021). İnfertilite ile ilgili hemşirelik alanında yürütülen lisansüstü tezler. Ordu Üniversitesi Hemşirelik Çalışmaları Dergisi, 4(1), 83-95. DOI: 10.38108/ouhcd.758439

Giriş 
İnfertilite, bir y1l ya da daha uzun bir süre korunmasız ve düzenli cinsel ilişkiye rağmen gebeliğin elde edilememesidir (Zegers Hochschild ve ark., 2017). İnfertilite Dünya Sağl1k Örgütü tarafindan üreme sistemi fonksiyonlarının bozulması ve belirgin bir sakatlık durumu olarak tanımlamıştır (WHO 2011). Primer infertilitede gebelik hiç oluşmaz iken, sekonder infertilitede önceden ölü veya canlı doğumla sonuçlanan en az bir gebelik öyküsü bulunmaktadır (Zegers Hochschild ve ark., 2017). Üreme çağındaki çiftlerin \%8-12'sinin infertiliteden etkilendiği belirtilmektedir (Inhorn ve Patrizio, 2015). İnfertilite oranları ülkeler arasında farklılık göstermektedir. $\mathrm{Bu}$ oranların \%5-30 arasinda değiştiği belirtilmektedir (Anokye ve ark., 2017). Sahra altı Afrika, Kuzey Afrika/Orta Doğu, Orta/Doğu Avrupa ve Güney/Orta Asya'da infertilite oranlarının diğer bölgelere kıyasla oldukça yüksek olduğu rapor edilmiştir (Mascarenhas ve ark., 2012). Bu durum gelişmekte olan ülkelerde erken yaşta evliliklere bağlı cinsel yolla bulaşan hastalıklara maruz kalma ve buna bağlı olarak gelişen pelvik ve genitoüriner sistem enfeksiyonlarından kaynaklanabilmektedir. Benzer şekilde, çok eşli evliliklerin bu ülkelerde daha yaygın olması sebebiyle HIV-1 enfeksiyonu gibi fertilitede azalma ile ilişkilendirilen enfeksiyonlarında etkili olabileceğine işaret edilmektedir (Agarwal ve ark., 2015). Ayrica bu ülkelerde infertil çiftlerin önemli bir bölümü üreme tedavisi hizmetlerinden maddi imkânsızlıklar nedeniyle yararlanamamaktadır (Ombelet 2011). Dünya genelinde ise 48,5 milyon çiftin infertilite sorunu yaşadığı tahmin edilmektedir (Mascarenhas ve ark., 2012).

İnfertilite sorunu, kadın, erkek veya her iki cinsiyete bağlı olarak ortaya çıkabilir. Kadına ait faktörler arasında; üreme organlarına ait anatomik sorunlar (konjenital anomaliler, deformiteler), menstruel siklus düzensizlikleri, enfeksiyonlara bağlı fizyolojik değişimler, hipo/hipertiroidizm, diyabetes mellitus, obezite ve hipertansiyon gibi birçok durum yer almaktadır (Altamimi ve ark., 2019). Erkeğe ait faktörlerde, hipotalamus, hipofiz veya diğer organlardaki sorunlara bağl1 olarak hipotalamik pituiter aksisin fonksiyonlarında bozukluklar, genetik faktörler, spermlerin taşınmasını engelleyen duktal sisteme yönelik sorunlar yer almaktadır (Altamimi ve ark., 2019). İleri yaş, sigara veya madde kullanımı, toksinlere maruziyet, yetersiz beslenme gibi çevresel ve mesleki diğer faktörlerde fertilitede azalmaya ve infertilite gelişmesine neden olabilir. Ayrıca bazı durumlarda infertilite nedeni belirlenememektedir. $\mathrm{Bu}$ durumda ise nedeni açıklanamayan infertiliteden söz edilir (Altamimi ve ark., 2019). Ek olarak, infertilite nedeninin sadece tıbbi faktörlere bağlı olmadığ 1 , psikolojik faktörler ile de ilişkili olabileceği belirtilmektedir. Psikolojik olarak kişilerin gebeliğe bağlı vücut şeklinin bozulacağ 1 endişesi, doğumda kendisinin veya bebeğinin öleceği korkusu veya iyi bir anne olamayacağ düşüncelerinin psikolojik olarak infertiliteye neden olabileceği belirtilmiștir. Bu durumlarda kadınların duygularını ifade edebilmesine olanak tanınması ve eşler arasında daha şefkatli bir bağ kurulmasının gebeliğin sağlanmasına yardımc1 olabileceği düşünülmektedir (Hocaoglu 2019).

Fertilite, insan yaşamının önemli parçalarından biridir. Bu sebeple fertilitenin kaybı evlilik, özsayg1 ve cinsel yaşamla ilgili sorunların ortaya çıkmasına ve gelecekle ilgili kaygıların olușmasına neden olmaktadır (Hocaoglu 2019). Bazı toplumlarda çocuk sahibi olmak veya çok sayıda çocuğa sahip olmak toplumsal bir statü sembolü olarak görülebilmektedir. $\mathrm{Bu}$ nedenle infertil çiftler kültürel ve toplumsal baskilara maruz kalabilmektedirler (Anokye ve ark., 2017). Bu yönüyle infertilite, bireylerin yaşamlarını fiziksel, cinsel ve sosyal yönlerden etkileyerek psikososyal ve psikoseksüel açıdan birçok sorunun gelişmesine neden olan önemli bir sağlık sorunudur (Gameior ve ark., 2014; Luk ve Loke, 2015). İnfertilitenin bireylerin kişiliğini, kimliğini, yaşamını, işini ve yaşam kalitesini etkilediği belirtilmektedir (Sathiyanarayanan ve ark., 2014). İnfertilite nedeni ile infertil kadın ve/veya erkelerin sosyal izolasyona, stigmaya, sözlü ve fiziksel istismara maruz kaldıkları ve yüksek düzeyde umutsuzluk yaşadıkları vurgulanmıştır (Anokye ve ark., 2017). İnfertil kadınlarda anksiyete, depresyon, stres, sosyal izolasyon, stigma, cinsel sorunlar ve intihar riski gibi psikososyal ve psikosesksüel sorunların ortaya çıkabileceği bildirilmiştir (Kjaer ve ark.; 2011; Lakatos ve ark., 2017; Maroufizadeh ve ark., 2017; Sis Çelik ve Kırca, 2018; Ozturk ve ark., 2019). İnfertil erkeklerde de stres, anksiyete, depresyon ve intihar düşünceleri gibi psikolojik sikıntıların ve erektil disfonksiyon gibi cinsel sorunların gelişebildiği belirtilmiştir (Gao ve ark., 2013; Ozkan ve ark., 2015; Yang ve ark., 2017). İnfertilitenin bütün bu psikolojik etkilerine rağmen bireyler bu sorunu paylaşmaktan çekinebilir ve sorunlarını gizli tutmak isteyebilirler. Bu durum ise bireylerin destek sistemlerinden mahrum kalmasina 
neden olmaktadır (Sezgin ve Hocaoglu, 2014). İnfertilite tanısının yanı sıra infertilite tedavi süreci de oldukça sıkıntılı bir süreçtir ve bireyleri fiziksel, sosyal, zihinsel ve cinsel olmak üzere birçok yönden olumsuz etkileyebilmektedir ( Goker ve ark., 2018; Obeidat ve ark., 2014). İnfertilite tedavilerinde uygulanan tıbbi müdahalelerin çeşitliliği, infertilitenin bireyler üzerindeki olumsuz etkilerini daha da şiddetlendirebilmektedir (Kroemeke ve Kubicka, 2018). Bu olumsuz etkilere bağlı olarak da infertil çiftlerin tedavilerini yarıda bırakabildikleri belirtilmiştir (Brandes ve ark., 2009; Shin ve ark., 2020).

Hemşirelik eğitiminde, lisans eğitimini takiben yüksek lisans ve doktora eğitimi aşamaları yer almaktadır (Büyükkaya Besen 2016). Yüksek lisans eğitimi, öğrencilerin belli bir konuda uzmanlaştığı ve bu süreçte problem çözme, akademik yazı yazma ve sözlü sunum yapabilme becerilerini kazandıkları bir süreçtir (Büyükkaya Besen 2016). Hemşirelik yüksek lisans eğitimlerinin bir diğer amacı da ileri hemşirelik uygulamalarının kazanımı ile hemşireleri doktora eğitimine hazırlamaktır (Boore 1996). Doktora eğitiminde de, teorik bilgilerin kapsamlı ve derinlemesine öğrenilmesi, kanıta dayalı uygulamaların kullanımının sağlanması, analitik düşünme becerisinin kazandırılması, hemşirelik araştırmalarının öneminin kavranması ve mesleğe yönelik değerlerin oluşumunun sağlanması amaçlanmaktadır (Ergöl 2011). Hemşirelik lisansüstü eğitiminin sonunda bir tez çalışması yapılmaktadır. Hemşirelik alanında daha çok tanımlayıcı, karma, deneysel ve yarı deneysel türde tez çalışmalarının bulunduğu belirtilmektedir (Büyükkaya Besen 2016).

İnfertilite, araştırmacılar ve akademisyenlerin fertilite ile ilgili mevcut durumu iyileştirmeye çalıştıkları uzmanlık alanları arasında yer alan önemli bir konudur (Makkizadeh ve Sa'adat, 2017). Yapılan çalışmalarda infertilitenin sosyal, kültürel, fiziksel, psikolojik ve ekonomik olmak üzere birçok alanda önemli etkilerinin olduğu belirlenmiştir (Anokye ve ark., 2017; Bakhtiari ve ark., 2016; Dong ve ark., 2013; Gao ve ark., 2013; Lakatos ve ark., 2017; Sezgin ve Hocaoglu, 2014). Bu noktada infertilite alanının hassas, üzerinde dikkatle durulması gereken, yeniliklere ve gelişmelere ihtiyaç duyulan bir alan olduğu görülmektedir. $\mathrm{Bu}$ sebeple, bilimsel ve kültürel anlamda ilerlemelerin sağlanabilmesi için bu alanın farklı yönleriyle ele alınması ve ilgili verilere ulaşılabilmesi kritik önem taşımaktadır (Makkizadeh ve Sa'adat, 2017). Bu doğrultuda infertiliteyi ve infertil bireyleri farkl yönlerden ele alan birçok yüksek lisans ve doktora tez çalışması bulunmaktadır. $\mathrm{Bu}$ retrospektif tanımlayıcı çalışmanın amacı, 2000-2019 yılları arasında infertilite ile ilgili yapılmış hemşirelik lisansüstü tezlerini genel boyutları ile değerlendirmektir.

\section{Yöntem}

\section{Çalışmanın Türü ve Örneklemi}

Bu çalışma, retrospektif tanımlayıcı bir çalışma olarak yapılmıştır. $\mathrm{Bu}$ çalışmanın örneklemine, online tarama sonucunda ulaşabilen infertilite alanında yapılmış 44 hemşirelik yüksek lisans ve 12 doktora tezi dâhil edilmiştir.

\section{Çalışma Stratejisi ve Verilerin Toplanması}

Yükseköğretim Kurumu (YÖK) sisteminde "infertilite", "infertil", "fertilite", "fertil" ve "'hemşirelik" anahtar kelimeleri ile yapılan online tarama sonucunda, 2000-2019 yılları arasinda yapılmış 399 adet yüksek lisans, doktora ve tıpta uzmanlık tezine ulaşılmıştır.

Tezlerin incelenmesi üç aşamada gerçekleştirilmiştir. İlk aşamada; hemşirelik alanı dışında infertilite ile ilgili yapılmış yüksek lisans, doktora tezleri ve tıpta uzmanlık tezleri (336 tez) çalışma dışı bırakılmıştır. İkinci aşamada; hemşirelik alanında yer alan 63 hemşirelik yüksek lisans ve doktora tezinden Doğum ve Kadın Hastalıkları Hemşireliği alanında yapılan yedi ebelik yüksek lisans tezi çalışma dışı bırakılmıștır. Üçüncü aşamada ise geriye kalan hemşirelikte 44 yüksek lisans ve 12 doktora tezi olmak üzere 56 lisansüstü tez çalışması değerlendirmeye alınmıştır (Şekil 1).

\section{Çalışma Verilerinin İncelenmesi}

Tezlerin incelenmesi sürecinde bir tez ortalama 15 dakika süresince araştırmacı tarafindan değerlendirilmiştir. Tezlerin incelenme süreci de iki adımlı olarak gerçekleşmiştir. İlk olarak tez sahibinin cinsiyeti, tezin yapıldığı anabilim dalı, tez çalışmasının yılı, tezin yapıldığı coğrafi bölge ve çalışmanın türü değerlendirilmiştir. İkinci aşamada hemşirelik yüksek lisans ve doktora tezleri araştırmacılar tarafindan oluşturulan başlıklar altında; çalışmanın amacı, çalışılan bireyin cinsiyeti ve grubun özelliği, konu başlığı, hastalarda veya hemşirelerde değerlendirilen alanlar ve tez çalışmasında ölçek kullanılma durumu olarak değerlendirilmiştir. Tezlerin yayın olma durumları tez ile ilgili genel bilgiler (tez sahibi ve danışmanın adı ve soyadı, tez çalışmasının adı ve anahtar sözcükler) yazılarak, Google Scholar ve Google arama motorunda hem Türkçe hem de İngilizce 
olarak, Pubmed, Science Direct, Medline, Springer Link veri tabanlarında İngilizce olarak taranmıştır.

Anahtar kelime: İnfertilite, İnfertil, Fertilite, Fertil, Hemșirelik

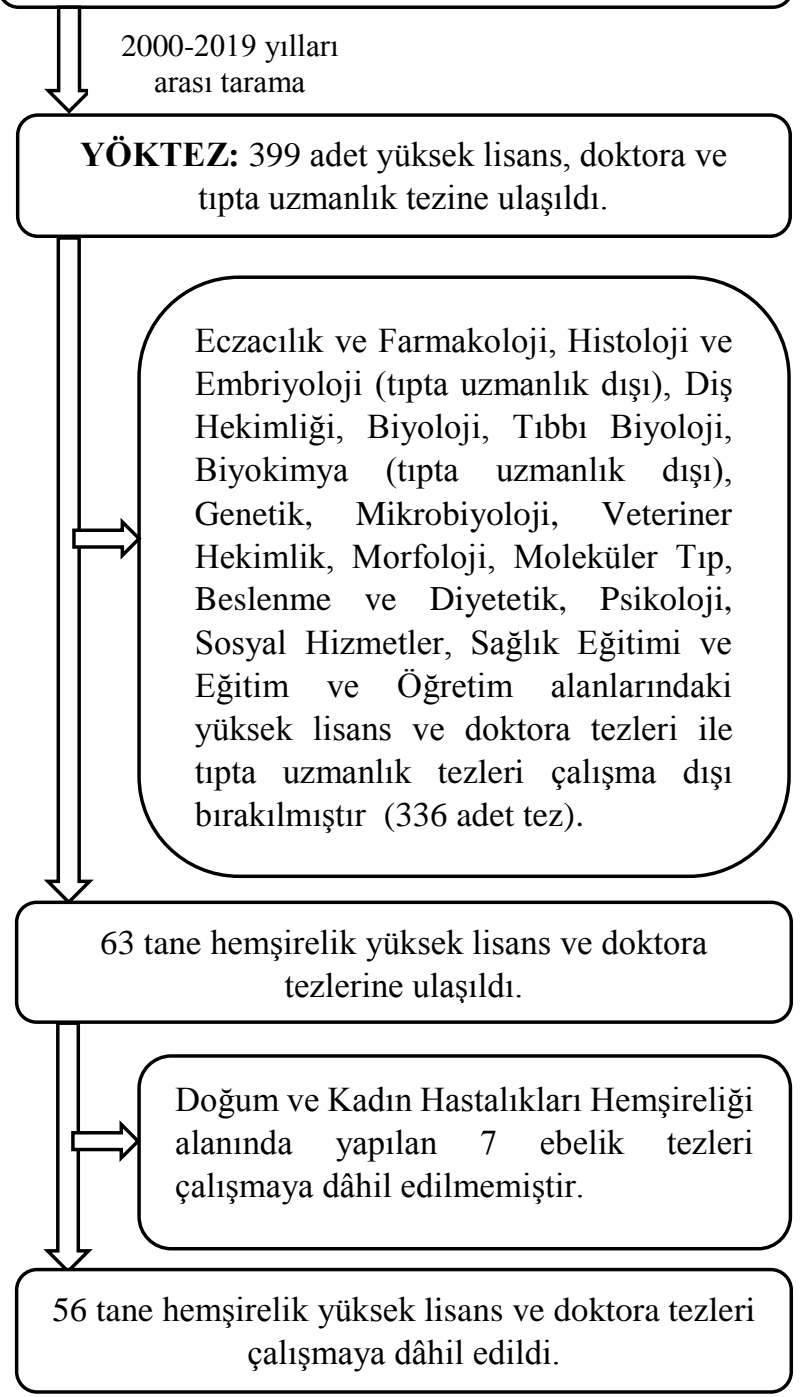

Şekil 1. Araştırmanın Akış Şeması

\section{Çalışmada Elde Verilerin Değerlendirilmesi}

Elde edilen saysal veriler SPSS 25.0 programında say1 ve yüzdelik olarak değerlendirilmiştir. Kategorize edilen değişkenler için frekans tabloları oluşturulmuştur.

\section{Bulgular}

Tablo 1 incelendiğinde; çalışmaya dâhil edilen infertilite alanından yapılmış hemşirelik tezlerinin \%78.6's1 yüksek lisans, \%21.4'ü doktora tezidir. Hemşirelik yüksek lisans tezlerinin \%95.4'ü Doğum ve Kadın Hastalıkları Hemşireliği, \%2.3'ü Halk Sağlığı Hemşireliği ve \%2.3’ü Psikiyatri
Hemşireliği alanında yapılmıștır. Doktora tezlerinin \%91.7'si Doğum ve Kadın Hastalıkları Hemşireliği ve \%8.3'ü Psikiyatri Hemşireliği alanında yapılmıştır.

Tablo 1. İnfertilite Alanında Yapılmış Hemşirelik Yüksek Lisans ve Doktora Tezleri ve Araştırmacılar İle İlgili Tanıtıcı Bilgiler

\begin{tabular}{|c|c|c|c|c|}
\hline \multirow[t]{2}{*}{$\begin{array}{l}\text { Lisansüstï tezler/ } \\
\text { araştırmacıların } \\
\text { tanıtıcı özellikleri }\end{array}$} & \multicolumn{2}{|c|}{$\begin{array}{l}\text { Hemşirelik } \\
\text { (Yüksek } \\
\text { Lisans) } \\
\end{array}$} & \multicolumn{2}{|c|}{$\begin{array}{l}\text { Hemşirelik } \\
\text { (Doktora) }\end{array}$} \\
\hline & $\mathbf{n}$ & $\%$ & $\mathbf{n}$ & $\%$ \\
\hline \multicolumn{5}{|l|}{ Araştırmacının } \\
\hline Kadın & 42 & 95.5 & 12 & 100 \\
\hline Erkek & 2 & 4.5 & 0 & 0 \\
\hline $\begin{array}{l}\text { Tezin Yapıldığı } \\
\text { Anabilim Dalı } \\
\text { Doğum ve Kadın }\end{array}$ & \multicolumn{4}{|c|}{ Anabilim Dalı } \\
\hline Hastalıkları Hemşireliği & 42 & 95.4 & 11 & 91.7 \\
\hline Halk Sağ & 1 & 2.3 & 0 & 0 \\
\hline Psikiyatri Hemşireliği & 1 & 2.3 & 1 & 8.3 \\
\hline \multicolumn{5}{|l|}{ Tezin Yılı } \\
\hline 2000-2004 & 2 & 4.5 & 0 & 0 \\
\hline $2005-$ & 11 & 25 & 1 & 8.3 \\
\hline 2010-2014 & 7 & 15.9 & 7 & 58.3 \\
\hline 2015-2019 & 24 & 54.5 & 4 & 33.3 \\
\hline \multicolumn{5}{|l|}{ Tez Çalıșmasının Türü } \\
\hline Tanımlayıcı yöntem & 26 & 59.1 & 0 & 0 \\
\hline Kesitsel & 6 & 13.6 & 0 & 0 \\
\hline Vaka-kontrol & 1 & 2.3 & 1 & 8.3 \\
\hline $\begin{array}{l}\text { Randomize kontrollü } \\
\text { çalışma }\end{array}$ & 0 & 0 & 5 & 41.7 \\
\hline Nitel çalışma & 1 & 2.3 & 3 & 25 \\
\hline $\begin{array}{l}2 \text { veya daha fazla } \\
\text { çalışma yönteminin } \\
\text { birlikte kullanıldığ }\end{array}$ & & & & \\
\hline çalışmalar & 10 & 22.7 & 3 & 25 \\
\hline \multicolumn{5}{|l|}{ Lisansüstü Eğitimin } \\
\hline Akdeniz & 4 & 9.1 & 0 & 0 \\
\hline Ege & 7 & 15.9 & 6 & 50 \\
\hline Marmar: & 15 & 34.1 & 5 & 41.7 \\
\hline Karadeniz & 1 & 2.3 & 0 & 0 \\
\hline İç Anadolu & 8 & 18.2 & 0 & 0 \\
\hline \multicolumn{5}{|l|}{ Doğu ve Güneydoğu } \\
\hline Anadolu & 9 & 20.4 & 1 & 8.3 \\
\hline \multicolumn{5}{|l|}{$\begin{array}{l}\text { Tezin Yayın Olma } \\
\text { Durumu }\end{array}$} \\
\hline Dergide yayınla & 13 & 29.5 & 10 & 83.3 \\
\hline $\begin{array}{l}\text { Kongrede bildiri olarak } \\
\text { sunulan }\end{array}$ & 3 & 6.8 & 0 & 0 \\
\hline $\begin{array}{l}\text { Yayınlanmayan/ } \\
\text { Ulaşılamayan }\end{array}$ & 28 & 63.6 & 2 & 16.7 \\
\hline
\end{tabular}


İnfertilite alanında yapılmış hemşirelik yüksek lisans tezlerinde araştırmacıların \%95.5'i kadın ve $\% 4.5$ 'i erkektir. İnfertilite ile ilgili hemşirelik yüksek lisans tezlerinin; $\% 54.5$ 'i $2015-2019, \% 25$ ' $\mathrm{i}$ 2005-2009, \%15.9'u 2010-2014 ve \%4.5'i 20002004 yılları arasında yapılmıştır. Hemşirelik yüksek lisans eğitimlerinin; \%34.1'i Marmara, \%20.4'ü Doğu ve Güneydoğu Anadolu, \%18.2'si İç Anadolu, \%15.9'u Ege, \%9.1'i Akdeniz ve \%2.3'ü Karadeniz bölgelerinde yer alan illerde alınmıştır. Hemşirelik doktora tezlerinde ise araştırmacıların tamamı kadındır. İnfertilite ile ilgili hemşirelik doktora tezlerinin; \%58.3'ü 2010-2014, \%33.3'ü 2015-2019 ve \%8.3'ü 2005-2009 yılları arasında yapılmıştır. Hemşirelik doktora eğitimlerinin; \%50'si Ege, \%41.7'si Marmara ve \%8.3'ü Doğu ve Güneydoğu Anadolu bölgelerinde yer alan illerde alınmıştır. Hemşirelik yüksek lisans tezlerinin; \%59.1'i tanımlayıcı, \%22.7'si iki veya daha fazla yöntemin birlikte kullanıldığı çalışma tipinde, \%13.6's1 kesitsel, \%2.3'ü vaka kontrol ve \%2.3'ü nitel deseni ile yapılmıştır. Hemşirelik doktora tezlerinin; \%41.7'si randomize kontrollü, \%25'i nitel, \%25'i de iki veya daha fazla yöntemin birlikte kullanıldığı çalışma tipinde ve \%8.3'ü vaka-kontrol araştırma türünde yapılmıştır. İnfertilite alanında yapılmış hemşirelik yüksek lisans tezlerinin \%63.6's1 yayınlanmamış/ulaşılamamış, \%29.5'i bilimsel bir dergide yayınlanmış ve $\% 6.8$ 'i kongrede sunulmuştur. Doktora tezlerinin ise \%83.3'ü yayına dönüştürülmüş ve \%16.7'si yayınlanmamış/ ulaşılamamıştır (Tablo 1).

Yapılan tezlerde çalışmaların amacı; yüksek lisans tezlerinin \%95.4'ü hasta merkezli iken, doktora tezlerinin tamamı hasta merkezlidir. Ayrıca yüksek lisans tezlerinin \%2.3'ü hemşirelerin yaşadığı güçlükler ve \%2.3'ü hemşirelerin mesleki rolleri/tutumlar1/görüşleri ile ilgilidir. Hemşirelik yüksek lisans tez çalışmalarında çalışmaya dâhil edilen bireylerin \%61.4'ü kadın, \%31.8'i karma ve $\% 6.8$ 'i erkektir. Çalışılan grubun \%77.3'ü infertil, $\% 18.2$ 'si hem fertil hem de infertil kadın ve/veya erkeklerden ve $\% 4.5^{\prime} \mathrm{i}$ hemşire/sağllk profesyonelinden oluşmaktadır. Doktora tezlerinde çalışmaya dâhil edilen bireylerin \%83.3'ü kadın ve \%16.7'si karmadır (erkek ve kadınlardır) ve çalış1lan grubun \%91.7'si infertil, \%8.3'ü hem fertil hem de infertil kadın ve/veya erkeklerden oluşmuştur (Tablo 2).

Tablo 2. İnfertilite Alanında Yapılmış Hemşirelik Yüksek Lisans ve Doktora Tezleri İle İlgili Genel Bilgiler

\begin{tabular}{|c|c|c|c|c|}
\hline \multirow[b]{2}{*}{ Tezler İle İlgili Genel Bilgiler } & \multicolumn{2}{|c|}{$\begin{array}{l}\text { Yüksek } \\
\text { Lisans }\end{array}$} & \multicolumn{2}{|c|}{ Doktora } \\
\hline & $\mathbf{n}$ & $\%$ & $\mathbf{n}$ & $\%$ \\
\hline \multicolumn{5}{|l|}{ Çalışmanın Amacı } \\
\hline Hemşirelerin yaşadıkları güçlükler & 1 & 2.3 & 0 & 0 \\
\hline Mesleki roller, tutumlar, görüşler & 1 & 2.3 & 0 & 0 \\
\hline \multicolumn{5}{|l|}{ Hasta merkezli } \\
\hline $\begin{array}{l}\text { - Belirteçleri, düzeyleri, uyumları, deneyimleri, algıları, baş etme yöntemlerini, } \\
\text { gereksinimleri, sonuçlara etkisini belirleme ve/veya karşılaștırma }\end{array}$ & 20 & 45.4 & 2 & 16.7 \\
\hline - $\quad$ İlişkileri/etkileri veya etkileyen faktörleri inceleme & 21 & 47.7 & 4 & 33.3 \\
\hline $\begin{array}{l}\text { - Hemşirelik bakımı uygulama (Kurama yönelik bakım, temel hemşirelik bakımı, yoga, } \\
\text {... vb.) ve sonuçları değerlendirme ve/veya karşıllaştırma }\end{array}$ & 0 & 0 & 3 & 25 \\
\hline - $\quad$ Eğitimi/danışmanlık hizmetini değerlendirme ve/veya karşılaştırma & 1 & 2.3 & 3 & 25 \\
\hline \multicolumn{5}{|l|}{ Calışılan Bireylerin Cinsiyeti } \\
\hline - Kadin & 27 & 61.4 & 10 & 83.3 \\
\hline - $\quad$ Erkek & 3 & 6.8 & 0 & 0 \\
\hline - Her iki cinsiyet & 14 & 31.8 & 2 & 16.7 \\
\hline \multicolumn{5}{|l|}{ Çalıșılan Grubun Özelliği } \\
\hline - Fertil kadın ve/veya erkek & 0 & 0 & 0 & 0 \\
\hline - İnfertilite tanısı almış kadın ve/veya erkek & 34 & 77.3 & 11 & 91.7 \\
\hline - Hem fertil hem infertil kadın ve/veya erkek & 8 & 18.2 & 1 & 8.3 \\
\hline - Hemşireler/Sağlık Profesyoneli & 2 & 4.5 & 0 & 0 \\
\hline \multicolumn{5}{|l|}{ Konu Başlıklarının Dağılımı } \\
\hline - Alg1 düzeylerini belirleme ve/veya karşılaştırma & 4 & 8.3 & 0 & 0 \\
\hline - Eğitim/danısmanlık verme ve sonuclarını değerlendirme & 1 & 2.1 & 3 & 20 \\
\hline - Hemşirelerin yaşadıkları güçlükler/tutum ve görüşleri & 2 & 4.2 & 0 & 0 \\
\hline
\end{tabular}


Tablo 2. (Devam) İnfertilite Alanında Yapılmış Hemşirelik Yüksek Lisans ve Doktora Tezleri İle İlgili Genel Bilgiler

\begin{tabular}{|c|c|c|c|c|}
\hline \multirow[b]{2}{*}{ Tezler İle İlgili Genel Bilgiler } & \multicolumn{2}{|c|}{$\begin{array}{l}\text { Yüksek } \\
\text { Lisans }\end{array}$} & \multicolumn{2}{|c|}{ Doktora } \\
\hline & $\mathbf{n}$ & $\%$ & $\mathbf{n}$ & $\%$ \\
\hline $\begin{array}{l}\text { Konu Başlıklarının Dağılımı } \\
\text { - İlişkiyi değerlendirme, etkileyen faktörleri/etkilenme düzeyini belirleme, } \\
\text { yaşam kalitesini, deneyimleri ve baş etme yöntemlerini belirleme } \\
\text { - İnfertilite ile ilgili geleneksel inançlar/uygulamalar } \\
\text { - Hemşirelik bakımı uygulama ve sonuçlarını değerlendirme } \\
\text { - Psikososyal/emosyonel sorunları ve/veya bakım gereksinimlerini belirleme } \\
\text { - Uyum düzeylerini ve/veya etkilerini belirleme ve/veya karş1laştırma }\end{array}$ & $\begin{array}{l}26 \\
2 \\
0 \\
5 \\
8\end{array}$ & $\begin{array}{c}54.2 \\
4.2 \\
0 \\
10.4 \\
16.6\end{array}$ & $\begin{array}{l}7 \\
0 \\
3 \\
1 \\
1\end{array}$ & $\begin{array}{c}46.7 \\
0 \\
20 \\
6.7 \\
6.7\end{array}$ \\
\hline $\begin{array}{l}\text { Tastalarda Değerlendirilen Alanlar } \\
\text { - Algılanan aile desteği } \\
\text { - Algılanan sosyal destek düzeyi } \\
\text { - } \text { Baş etme düumu (İnfertilite, stres, depresyon, ... vb.) } \\
\text { - Benlik saygısı } \\
\text { - } \text { Bilgi düzeyi } \\
\text { - Cinsel uyum/Cinsel tutumlar/Cinsel sorunlar/Cinsel yaşam } \\
\text { - Çift Uyumu } \\
\text { - Damgalama/Stigmadan etkilenme } \\
\text { - Depresyon düzeyi } \\
\text { - Evygusal okuryazarlık } \\
\text { - Eğitim/danumuşmanlık sonuçlarını değerlendirme } \\
\text { - Fertiliteye uyum düzeyi } \\
\text { - Geleneksel inançlar/uygulamalar } \\
\text { - Hemşirelik bakımı (Bakımın kalitesi, hasta memnuniyeti, ... vb.) } \\
\text { - İnfertiliteden etkilenme durumu } \\
\text { - İş yaşamı/Çalışma hayatı } \\
\text { - Öutluluk düzeyi } \\
\text { - Psikosososyal/emosyonel etkilenme düzeyi } \\
\text { - Stres düzeyi } \\
\text { - Tanı ve tedavi süreci ile ilgili deneyimler/beklentiler } \\
\text { - Umutsuzluk düzeyi } \\
\text { - Yalnızlık düzeyi } \\
\text { - Yaşam biçimi davranışı } \\
\end{array}$ & $\begin{array}{c}1 \\
5 \\
4 \\
4 \\
1 \\
1 \\
10 \\
3\end{array}$ & $\begin{array}{c}1.3 \\
6.5 \\
5.2 \\
5.2 \\
1.3 \\
1.3 \\
12.9 \\
3.9 \\
6.5 \\
11.7 \\
1.3 \\
5.2 \\
0 \\
2.6 \\
2.6 \\
0 \\
0 \\
1.3 \\
1.3 \\
0 \\
7.8 \\
3.9 \\
1.3 \\
3.9 \\
2.6 \\
2.6 \\
7.8 \\
\end{array}$ & $\begin{array}{l}0 \\
0 \\
1 \\
4 \\
0 \\
0 \\
0 \\
1 \\
1 \\
1 \\
1 \\
0 \\
0 \\
0 \\
1 \\
3 \\
3 \\
0 \\
0\end{array}$ & $\begin{array}{c}0 \\
0 \\
3.8 \\
15.4 \\
0 \\
0 \\
3.8 \\
3.8 \\
3.8 \\
0 \\
0 \\
3.8 \\
11.5 \\
0 \\
0 \\
7.7 \\
7,7 \\
0 \\
0 \\
3.8 \\
3.8 \\
19.2 \\
0 \\
3.8 \\
0 \\
3.8 \\
3.8 \\
\end{array}$ \\
\hline $\begin{array}{l}\text { mşirelerde Değerlendirilen Alanlar } \\
\text { - } \quad \text { Hemşirelik rolleri } \\
\text { - } \quad \text { İfertiliteye yönelik tutumlar } \\
\text { - } \quad \text { Yardımcı üreme tedavilerine yönelik görüşler } \\
\text { - } \quad \text { Yaşadıkları güçlükler }\end{array}$ & $\begin{array}{l}1 \\
1 \\
1 \\
1\end{array}$ & $\begin{array}{l}25 \\
25 \\
25 \\
25\end{array}$ & $\begin{array}{l}0 \\
0 \\
0 \\
0\end{array}$ & $\begin{array}{l}0 \\
0 \\
0 \\
0\end{array}$ \\
\hline
\end{tabular}

Hemşirelik yüksek lisans tezlerinin; \%54.2'si ilişki, etkilenme düzeyi, yaşam kalitesi ve baş etme yöntemlerini, \%16.6's1 uyum düzeylerini, \%10.4'ü psikososyal/emosyonel sorunları veya bakım gereksinimini, \%8.3'ü alg1 düzeylerini, \%4.2'si geleneksel inanç ve uygulamaları, \%4.2'si hemşirelerin yaşadıkları güçlükler ve tutumları ve $\% 2.1$ 'i hasta eğitimini incelemişlerdir. Yüksek lisans tezlerinde çoğunlukla değerlendirilen alanlar; cinsellik (\%12.9), depresyon düzeyi (\%11.7), psikososyal/emosyonel etkilenme düzeyi (\%7.8), yaşam kalitesi (\%7.8), algılanan sosyal destek $(\% 6.5)$, damgalanma (\%6.5), anksiyete düzeyi (\%5.2) ve baş etme durumudur (\%5.2). Hemşirelerde değerlendirilen alanlar ise; hemşirelik rolleri (\%25), infertiliteye yönelik tutumlar (\%25), yardımcı üreme tekniklerine yönelik görüşler $(\% 25)$ ve hemşirelerin yaşadıkları güçlüklerdir (\%25). 
Doktora tezlerinin \%46.7'si ilişki, etkilenme düzeyi, yaşam kalitesi ve baş etme yöntemlerini, \%20'si hasta eğitimini, \%20'si hemșirelik bakımı ve sonuçlarını, \%6.7'si psikososyal/emosyonel sorunları ve bakım gereksinimlerini ve \%6.7'si uyum düzeyleri ile ilgili konuları araştırmışlardır. Doktora tezlerinde çoğunlukla değerlendirilen alanlar; stres düzeyi (\%19.2), baş etme durumu $(\% 15.4)$ ve eğitim/danışmanlık sonuçlarını değerlendirmedir (\%11.5) (Tablo 2).

Hemşirelik yüksek lisans tezlerinin \%84.1'inde ve doktora tezlerinin ise \%58.3'ünde ölçek kullanılmıştır. Hemşirelik doktora tezlerinin \%8.3'ünde ölçek geçerlik ve güvenirliği yapılmıştır (Tablo 2). Hemşirelik yüksek lisans tezlerinde en sık kullanılan ölçekler: Arizona Cinsel Yaşantılar Ölçeği, Beck Depresyon Ölçeği, Çok Boyutlu Algılanan Sosyal Destek Ölçeği, Doğurganlık Sorunları Yaşayan Kişiler için Hayat Kalitesi Ölçeği, Evlilikte Uyum Ölçeği, İnfertilite Etkilenme Ölçeği ve SF36 Yaşam Kalitesi Ölçeği'dir. Hemşirelik doktora tezlerinde en sık kullanılan ölçekler: Beck Depresyon Ölçeği, Çiftler Uyum Ölçeği, Fertiliteye Uyum Ölçeği, İnfertilite Etkilenme Ölçeği, İnfertilite Öz-Yeterlik ÖlçeğiKısa Formu, İnfertilite Stresi Ölçeği, İnfertilite Stresi ile Başa Çıkma Ölçeği, Spielberger'in Durumluk ve Süreklilik Anksiyete Ölçeği, Stresle Başa Çıkma Tarzları Ölçeği ve WHOQOL-BREF Yaşam Kalitesi Ölçeği'dir (Tabloda gösterilmemiştir).

\section{Tartışma}

Fertilite, insan yaşamı üzerinde çok yönlü etkileri olan, insan bedeninin sahip olduğu fizyolojik özelliklerinden birisidir (Goli ve ark., 2012). Üreme yeteneği ve soyun devamı tüm canlı varlıklar için doğuştan gelen önemli içgüdülerden biridir (Hocaoglu 2019). İnfertilite ise, gebeliğin hiç oluşmadığı ya da en az bir kez gebelik meydana geldikten sonra tekrar gebeliğin oluşmadığı patolojik bir durumdur (Zeger Hochschild ve ark., 2017). Hem kadın hem de erkekler için infertilite durumu, stresli, psikolojik ve ekonomik yönden zorlayıc1 ve fiziksel olarak da acı verebilen karmaşık, durumsal bir kriz durumudur (Hocaoglu 2019). İnfertil bireylere yaklaşım, infertil bireyin cinsiyetine, infertilitenin nedenine, süresine ve bireylerin kişisel özelliklerine bağlı olarak farklılık göstermektedir (Anwar ve Anwar, 2016).

$\mathrm{Bu}$ retrospektif tanımlayıcı çalışmada, infertilite konusunda hemşirelik alanında yapılmış tezlerin büyük çoğunluğunun yüksek lisans tezlerinden oluştuğu görülmektedir. İnfertilite alanında yapılmış hemşirelik tezlerinin \%78.6's1 yüksek lisans, $\% 21.4$ 'ü ise doktora tezidir. Yüksel Koçak ve Büyükkayacı Duman (2019)'ın üreme sağlığı-cinsel sağlık alanında yapılmış hemşirelik tezlerini inceledikleri bir çalışmada; üreme sağlığı-cinsel sağl1k alanındaki tezlerin \%93.3'ünün yüksek lisans ve \%6.6'sının doktora tezi olduğu tespit edilmiştir. Üreme sağlığ 1 , fertilite ve infertilite ile ilgili yapılan hemşirelik lisansüstü tezlerinin büyük çoğunluğu yüksek lisans tezlerinden oluşmaktadır. Üreme sağlığı ve fertilite alanında yapılmış az sayıda doktora tezi bulunmaktadır.

İnfertilite ve fertilite konularında 1950'lerden önce yeteri kadar araştırma yapılmadığ 1 belirtilmektedir. İkinci Dünya Savaşı'nın ardından, ekonomik gelişmeleri takiben, fertilite ve infertilite alanlarına yönelik ilginin artmaya başladığı ifade edilmiştir (Szreter 1993). İn vitro fertilizasyon (IVF) ve yumurta bağışı gibi konuların 1980'lerden itibaren gündeme gelmesiyle birlikte infertilite alanında yapılan çalışmalar hız kazanmış ve 2002 yılı itibari ile bu alana yönelik yapılan çalışmalar büyük oranda artış göstermiştir (Johnson ve ark., 2018). Bu çalışmada, infertilite alanında yapılmış hemşirelik lisansüstü tezlerinde 2010 y1lı itibari ile artışın meydana geldiği görülmektedir. İnfertilite ile ilgili hemşirelik yüksek lisans tezlerinin çoğunluğu (\%54.5) 2015-2019 y1llar1 arasinda yapilırken, doktora tezlerinin çoğunluğu (\%58.3) 2010-2014 yılları arasında yapılmıştır (Şekil 2). Hemşirelik alanında infertilite konusunda yapılmış yüksek lisans tezlerinin $\% 95.5$ 'i kadın ve \%4.5'i erkek araştırmacılar tarafindan yapılmıştır. Doktora tezlerinin ise tamamı kadın araştırmacılar tarafından yapılmıştır (Tablo 1). Benzer şekilde Dağcı ve ark. (2019)'nın çalışmasında da 2011-2015 yılları arasında hemşirelik yüksek lisans ve doktora alanında yapılan tezler daha fazladır (sırasıyla \%25 ve \%34) ve araştırmacıların \%96.6'sı kadın, \%3.4'ü erkektir (Dağcı ve ark., 2019). Hemşirelik mesleği, kadın nüfusunun fazla olduğu ve toplum tarafindan belli bir cinsiyete özgü olduğuna yönelik algilara sahip bir meslektir (Meadus ve Twomey, 2011). Geçmişte hemşirelik alanında erkek hemşirelerin de hemşirelik mesleğinin gelişimine önemli katkıları olmuş olsa da zamanla, özellikle Florence Nightingale ile modern hemşireliğin başlamasından sonra, erkeklerin meslekte yeri tanınmamaya başlamış, hemşirelik mesleği kadına yakışan bir meslek olarak algılanmış ve erkekler meslek seçiminde hemşireliği tercih etmekten uzaklaşmışlardır (Hollup 2014; Meadus ve 
Twomey, 2011; O’Lynn 2013). Bu sebeple, mesleği tercih eden erkek hemşirelerin özellikle jinekoloji ve obstetri alanında çalışırken ve hemşirelik eğitimi sirasında bu birimlerde uygulama eğitimi almada sıkıntılar yaşadıkları belirtilmiştir (Meadus ve Twomey, 2011; Smith 2006). Hemşirelik mesleği geçmişten günümüze hem erkek hem de kadın bireyler tarafindan sürdürülen bir meslektir. Her bireyin farklı dünya görüşleri ve farklı fikirleri bulunmaktadir.

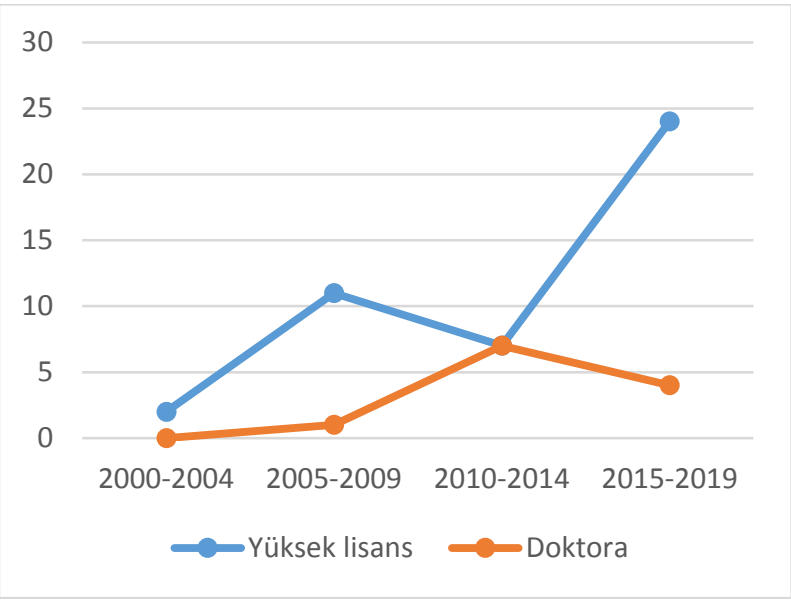

Şekil 2. Yüksek Lisans ve Doktora Tezlerinin Y1llara Göre Dağılımı

İnfertilite alanında yapılmış hemşirelik yüksek lisans eğitimlerinin \%34.1'i Marmara bölgesinde, doktora eğitimlerinin ise \%50'si Ege ve \%41.7'si Marmara bölgelerinde yer alan illerde gerçekleştirilmiştir (Tablo 1). Yüksel-Koçak ve Büyükkayacı-Duman (2019)'ın çalışmasında, hemşirelik lisansüstü tezlerinin \%46.6'sının İç Anadolu, \%33.3'ünün Marmara ve \%13.3'ünün Ege bölgesinde yürütüldüğü tespit edilmiştir. Ardahan ve Özsoy (2015)'un çalışmasında da hemşirelik yüksek lisans tezlerinin çoğunluğu Marmara (\%37.4), Ege (\%25.1) ve İç Anadolu (\%24.5) bölgelerinde, doktora tezlerinin ise büyük çoğunluğu Ege (\%38.9) ve Marmara (\%36.3) bölgelerinde yapılmıştır (Ardahan ve Özsoy, 2015). Marmara ve İç Anadolu bölgesinde yer alan illerde hemşirelikte lisansüstü eğitim veren devlet ve özel üniversitelerin fazla olmasi ve bu alanda uzmanlaşmış öğretim üyelerinin genellikle büyük şehirlerde bulunması sebebiyle hemşirelik lisansüstü çalışmalarının bu bölgelerde çoğunlukta olduğu yorumu yapılabilir.

$\mathrm{Bu}$ çalışmada, infertilite alanında yapılan hemşirelik yüksek lisans tezlerinin \%95.4'ünün, doktora tezlerinin ise \%91.7'sinin Doğum ve Kadın
Hastalıkları Hemşireliği alanında yapıldığı belirlenmiştir (Tablo 1). İnfertilite üreme sağlığ alanının önemli bir parçasıdır. Bu nedenle Doğum ve Kadın Hastalıkları Hemşireliği alanında lisansüstü eğitim gören hemşireler bu alanda da tez çalışması yapabilmektedir. Ancak infertilite psikolojik ve toplumsal yönden de çok boyutlu etkilere sahip bir alandır (Hocaoglu 2019). Bu sebeple Psikiyatri Hemşireliği ve Halk Sağlı̆̆ Hemşireliği alanlarında da yapılan tez çalışmaları bulunmaktadır.

İnfertilite alanında yapılmış hemşirelik yüksek lisans tezlerinin çoğu tanımlayıcı tipte $(\% 59.1 / 26$ çalışma) iken, en az vaka kontrol (\%2.3/1 çalışma) ve nitel çalışma (\%2.3/1 çalışma) yöntemi kullanılmıştır. Doktora tezlerinin ise \%41.7'si randomize kontrollü ( 5 çalışma), \%25'i nitel (3 çalışma) ve \%25'i iki veya daha fazla çalışma yönteminin birlikte kullanıldığ çalışma ( 3 çalışma) yöntemleri ile yapılmıştır (Tablo 1, Şekil 3). Ardahan ve Özsoy (2015)'un çalışmasında; hemşirelik yüksek lisans tezlerinin \%47.6'sının tanımlayıc1, \%34'ünün metodolojik, \%15.2'sinin deneysel ve \%3.4'ünün kayıt araştırmaları, doktora tezlerinin ise $\% 45.6$ 'sının tanımlayıcı, \%36.3'ünün metodolojik, \%16.8'inin deneysel ve \%1.3'ünün kayıt araştırmaları olduğu saptanmıştır. Dağcı ve ark. (2019)'nın çalışmasında ise cerrahi hemşireliği yüksek lisans tezlerinin büyük çoğunluğunu tanımlayıcı türdeki $(\% 43.9)$, doktora tezlerinin çoğunluğunu ise deneysel (\%6.6) ve yarı deneysel (\%4.6) türdeki çalışmaların oluşturduğu görülmüştür. Hemşirelik yüksek lisans tez çalışmaları daha çok tanımlayıcı çalışmaları içermektedir. Doktora tez çalışmaları ise çoğunlukla randomize kontrollü türde deneysel çalışmaları içermektedir. Hemşirelik lisansüstü eğitimi bir hemşirenin mesleki anlamda gelişimini adım adım sağlamaktadır. Bireylere temel olarak bir araştırmayı tasarlama ve yürütebilme becerisi kazandırılmakta ve hemşirelere araştırmacı yönlerini ve ilgi alanlarına keşfetme imkânı da tanımaktadır. İlerleyen süreçlerde ise mesleki anlamda daha yetkin ve yeterli konuma erişen hemşireler daha kapsamlı çalışmalar yapmaktadırlar.

$\mathrm{Bu}$ çalışmada; infertilite alanında yapılmış hemşirelik yüksek lisans tezlerinin $\% 29.5$ 'i, doktora tezlerinin ise \%83.3'ü bilimsel bir dergide yayınlanmıştır (Tablo 1). Hemşirelik yüksek lisans ve doktora tezlerinin yayın olma durumu ile ilgili yapılan bibliyometrik bir çalışmada; yüksek lisans tezlerinin \%14.4'ünün, doktora tezlerinin ise 
\%7.7'sinin yayına dönüştürüldüğü belirlenmiştir (Yılmaz ve ark., 2017). Yapılan çalışmanın sonuçları bizim çalışmamız ile farklılık göstermektedir. İnfertilite alanında yapılan doktora tezlerinin büyük çoğunluğu yayına dönüștürülmüștür. Ancak bu durum, infertilite alanında yapılmış az sayıda (12 adet) doktora tezine ulașılması ve bu tezlerin araștırmacılarının çoğunluğunun akademisyen olması ile açıklanabilir.

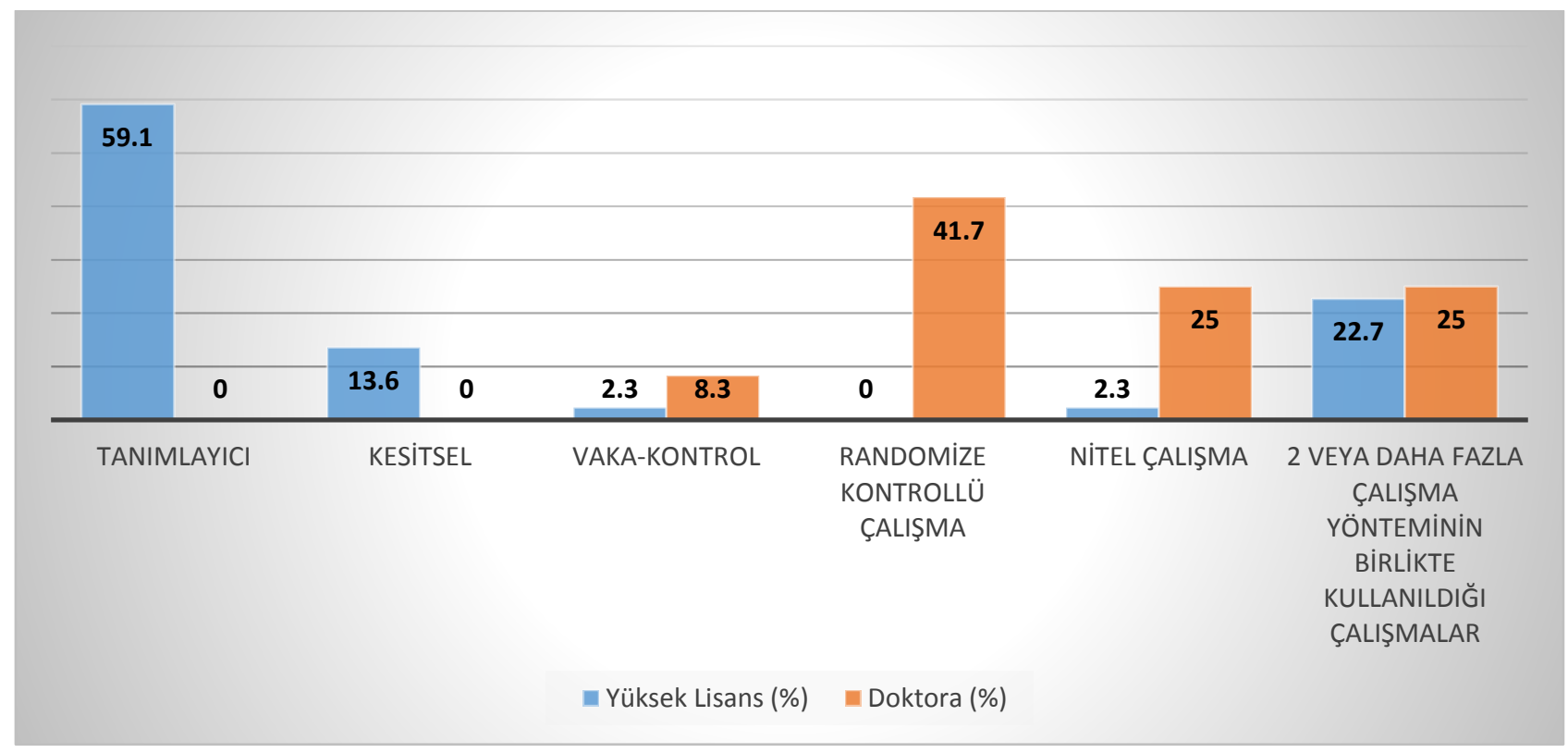

Şekil 3. Hemşirelik Yüksek Lisans ve Doktora Tezlerinde Kullanılan Çalışma Türleri

İnfertilite alanında yapılmış hemşirelik yüksek lisans tezlerinin büyük bir bölümünü (\%95.4), doktora tezlerinin tamamını hasta merkezli olan çalışmalar oluşturmuştur. Yüksek lisans tezlerinin \%4.6'sında hemşireler/sağlık profesyonelinin yaşadıkları güçlükler, mesleki roller, tutumlar ve görüşler ile infertilite alanında ilgili çalışmalar yapılmıştır. Doktora tezlerinde sağlık profesyoneli ile yapılan çalışma bulunmamaktadır. Hemşirelik yüksek lisans tezlerinin büyük çoğunluğunda, belirteçler, düzeyler, uyumlar, algilar, baş etme yöntemleri ve gereksinimleri belirlemek ve/veya karşılaştırmak (\%45.4) ve ilişkileri/etkileri veya etkileyen faktörler $(\% 47.7)$ gibi konular araştırılmıştır. Hemşirelik doktora tezlerinde ilişkiler/etkiler veya etkileyen faktörler (\%33.3), hemşirelik bakımı (\%25) ve eğitim/danışmanlık (\%25) konuları ele alınmıştır. İnfertilite alanında yapılan lisansüstü hemşirelik tezlerinde mesleki roller/tutumlar/görüşler ile ilgili çalışmalar sınırlı sayıdadır. Hemşirelerin değerlendirildiği alanda; hemşirenin rolleri, infertiliteye yönelik tutumlar, yardımc1 üreme tedavilerine yönelik görüşler ve yaşanılan güçlükler eşit düzeyde incelenmiştir (Tablo 2). Ardahan ve Özsoy (2015)'un çalışmasında; yüksek lisans tezlerinin \%35.3'ünde bilgi düzeyini belirleme, \%32.1'inde temel hemşirelik girişimi, \%26.6'sında kalite çalışmaları ve \%15.6'sinda hemșirenin rolleri çoğunluk olarak çalışma konularını oluşturmuştur. Doktora tezlerinde genellikle, kalite çalışmaları (\%34), bilgi düzeyini belirleme (\%32.7) ve hemşirelik girişimi (\%27) konuları incelenmiştir. Cerrahi Hastalıkları Hemşireliği lisansüstü tezleri ile ilgili yapılan bir çalışmada; yüksek lisans tezlerinin büyük çoğunluğunun bilgi toplama amacıyla yapıldı̆̆ 1 , mesleki roller/tutumlar/görüşlere yönelik yapılan çalışmaların çok az olduğu belirlenmiştir. Doktora tezlerinin büyük çoğunluğunun bakım kalitesini arttırmak ve bilgi toplamak amacıyla yapıldığı, mesleki roller/tutumlar/görüşlere yönelik yapılan çalışmaların benzer şekilde çok az olduğu görülmüştür (Dağc1 ve ark., 2019).

İnfertilite alanında yapılmış hemşirelik yüksek lisans tezlerinde daha çok cinsellik (\%12.9), yaşam kalitesi (\%7.8), depresyon düzeyi $(\% 11.7)$ ve psikososyal/emosyonel etkilenme düzeyi (\%7.8) ele alınırken, doktora tezlerinde baş etme durumu (\%15.4), eğitim/danışmanlık sonuçlarını değerlendirme $(\% 11.5)$ ve stres düzeyi $(\% 19.2)$ değerlendirilmiştir. İnfertilite alanında yapılmış hemşirelik yüksek lisans tezlerinde hemşirelik 
bakımı (kuram, temel uygulamalar, vb.) ve infertiliteden etkilenme hiç değerlendirilmemiştir. Hemşirelik yüksek lisans tezlerinde hemşirelerin değerlendirildiği alandaki alt boyutlarda; hemşirenin rolleri, infertiliteye yönelik tutumlar, yardımc1 üreme tedavilerine yönelik görüşler ve yaşanılan güçlükler eşit düzeyde incelenmiştir (Tablo 2).

İnfertilite sorunu hem kadın hem de erkeklerin deneyimlediği, psikososyal ve psikoseksüel boyutları olan evrensel bir sorundur (Luk ve Loke, 2015). Üreme çağındaki çiftlerin \%8-12'si infertiliteden etkilenmektedir (Inhorn ve Patrizio, 2015). Kadınların \%12.5'inin, erkeklerin ise \%10'unun infertiliteyi deneyimlediği belirtilmektedir (Datta ve ark., 2016). Ancak, infertilite hala sadece kadının yaşayabileceği bir sorun olarak algilanmakta ve bu süreçte erkeklerin duygu ve düşünceleri, deneyimleri ve yaşadığ 1 sorunlar yeteri kadar ele alınmamaktadır. Oysaki erkek kaynaklı infertilitenin bulunduğu durumlarda çiftlerde cinsel işlev bozukluğunun daha fazla görüldüğü bildirilmiştir (Bakhtiari ve ark., 2016; Lotti ve ark., 2016; Lotti ve Maggi, 2018; Punab ve ark., 2017). Bunun yanı sira infertil erkeklerde anksiyete, stres ve depresyon riskinin fertil erkeklere kıyasla daha yüksek olduğu belirtilmiştir (Ahmadi ve ark., 2011; Mikkelsen ve ark., 2013; Yang ve ark., 2017). Ayrica infertilite tedavi sürecinin infertil erkeklerde etkilerinin yeteri kadar değerlendirilmediği ifade edilmiştir (Dong ve ark., 2013). Hemşirelik yüksek lisans tezlerinin çoğunda çalışmaya kadınlar (\%61.4) dâhil edilmiş ve çalışma grubu olarak çoğunlukla infertilite tanısı almış kadın ve/veya erkekler (\%77.3) değerlendirilmiştir. Doktora tezlerinde çalışmaya kadın veya her iki cinsiyet dâhil edilmiş ve çoğunlukla infertilite tanısı almış kadın ve/veya erkekler üzerinde çalışılmıştır. Hemşirelik yüksek lisans tezlerinin \%18.2'sinin ve doktora tezlerinin \%8.3'ünün örneklemini hem fertil hem de infertil bireylerden oluşan karma bir grup oluşturmuştur (Tablo 2).

İnfertilite alanında yapılmış hemşirelik yüksek lisans tezlerinin \%84.1'inde ve doktora tezlerinin \%58.3'ünde ölçek kullanılmıştır. Doktora tezlerinin \%8.3'ünde ise ölçek geçerlik ve güvenirliği yapılmıştır (Tablo 2). İnfertilite alanında yapılmış hemşirelik lisansüstü tezlerinde ölçek geçerlik ve güvenirlik çalışmaları en az orana sahiptir ve ölçek geliştirmeye yönelik bir çalışmaya ulaşılmamıştır. Dağcı ve arkadaşlarının (2019) çalışmasında; Cerrahi Hastalıkları Hemşireliği yüksek lisans tezlerinde ölçek kullanılan çalışmaların daha az olduğu, doktora tezlerinde ölçek kullanımının daha fazla olduğu belirtilmiştir. Genel itibariyle lisansüstü tezlerde ölçek geliştirme çalışmalarının çok az olduğu tespit edilmiştir. Öncel ve Sümen (2017)'in Halk Sağlı̆̆ ile ilgili çalışmasında; yüksek lisans tezlerinin \%66.5'inde, doktora tezlerinin \%86.2'sinde ölçek kullanıldığ 1 bildirilmiştir. Yüksek lisans tezlerinin \%15.5'inin, doktora tezlerinin \%30.9'unun ölçek geliştirme veya uyarlanması ile ilgili çalışmalar olduğu belirtilmiştir. Ardahan ve Özsoy (2015)'un çalışmasında; hemşirelik yüksek lisans tezlerinin \%87.7'sinde ölçek kullanıldığ 1 , \%12.3'ünde ölçek geliştirildiği, doktora tezlerinin \%91.5'inde ölçek kullanıldığ $1, \% 8.5$ 'inde ölçek geliştirildiği tespit edilmiştir.

\section{Sonuc}

Hemşirelik lisansüstü tezlerinin çoğunluğunu yüksek lisans tezleri oluşturmaktadır. Benzer şekilde infertilite alanında yapılmış hemşirelik lisansüstü tezlerinin büyük çoğunluğu da yüksek lisans tezleridir. Doktora eğitiminde infertilite alanında yapılan çalışma oldukça sınırlıdır. Doktora eğitimi, hemşirelik eğitiminin önemli bir parçasıdır. $\mathrm{Bu}$ sebeple doktora tez çalışmalarında da infertilite ve infertil bireylere yönelik çalışmaların yapılmasının alana daha çok katkı sağlayacağı düşünülmektedir. Ayrıca infertilite alanında yapılan hemşirelik lisansüstü tezlerinin büyük çoğunluğu kadın araştırmacılar tarafindan yapılmıştır. Hemşirelik mesleği her iki cinsiyetten bireyin de yapabildiği bir meslek olmasına rağmen lisansüstü eğitim yapan hemşirelerin büyük çoğunluğu kadın hemşirelerdir. İnfertilite gibi yeniliğe ve gelişime ihtiyaç duyulan bir alanda hemşirelik adına bakıma yönelik gelişmelerin sağlanması için farklı fikirlere sahip olan kadın ve erkek her bireye ihtiyaç vardır. Ayrıca diğer çalışmalar ile benzer şekilde bu çalışmada da yayın haline getirilen tezlerin sayısının oldukça sınırlı olduğu görülmektedir. Hemşirelerin zaman ve emek harcayarak hazırladıkları tezlerini bilimsel yayınlara dönüştürmeleri, hem literatüre hem de meslektaşlarının farkındalığının artmasına ve hemşirelik mesleğinin gelişimine katk1 sağlayacaktır. İnfertilite alanında yapılan lisansüstü tezlerde çoğunlukla belirteçler, uyum düzeyleri, algılar ve ilişkili faktörler gibi konulara değinilmiştir. İnfertilite hemşirelik bakımına ihtiyacın çok fazla olduğu ve infertilite hemşirelerinin kendisini geliştirmesi gereken bir alandır. Bu sebeple hemşirelik bakım felsefeleri ve kuramları doğrultusunda bakım temelli çalışmalara 
ve hemșirelerin duygu, düşünce ve mesleki gelişimleri için yapabileceklerine odaklanan daha fazla çalıșmaya ihtiyaç duyulmaktadır. Ayrıca çalışılan bireylerin büyük çoğunluğu infertil kadınlardan oluşmuştur. İnfertilite sıklığ 1 kadın ve erkeklerde birbirine çok yakın bir değere sahiptir ve eşler bu süreci birlikte deneyimlemektedirler. İnfertilite nedeninin erkek olduğu durumlarda bile kadına birçok tedavi prosedürünün uygulanması, içinde yaşanılan toplumun sosyal, kültürel özellikleri ve ataerkil bir toplum yapısının bulunması gibi faktörlere bağlı olarak kadınlar infertiliteden psikolojik olarak ciddi boyutlarda etkilenmektedirler. $\mathrm{Bu}$ sebeple de yapılan araştırmalar çoğunlukla kadın merkezli olarak yapılıyor olabilir. Ancak bu süreçte erkeğin duygu ve deneyimlerinin de göz ardı edilmemesi gerekmektedir. Çünkü toplumun kültürel ve sosyal yapısı infertil erkekleri de psikososyal yönden etkileyebilmektedir. Bu noktada içinde yaşanılan kültürün çocuk sahibi olmaya yüklediği anlam, bunu sembolize etme durumu ve çocuğun ebeveynler için toplumsal bir statü anlamına gelip gelmediği iyi bir şekilde değerlendirilmelidir. Bu anlamda yapılacak hemşirelik araştırmalarının, toplumun infertiliteye yönelik algılarını ortaya çıkaracak, bireylerin ve meslektaşlarının farkındalığını arttıracak ve etkili çözüm yollarını üretebilecek veya gelişimine zemin hazırlayacak nitelikte olması gerekmektedir. Ayrıca infertilite alanında çalışan hemşirelerin fertilitenin korunmasına yönelik çalışmalar yapması ve fertil bireylerde de infertilite riski, eğitim ve farkındalık ile ilgili araştırmalarda bulunması gerekmektedir. $\mathrm{Bu}$ sayede risklere erken dönemde müdahale edilmesi ile kadın ve erkeklerde fertiliteye yönelik rahatsızlıkların getirebileceği bireysel, toplumsal ve ekonomik sorunların azaltılmasına veya önlenmesine yardımcı olacağı düşünülmektedir.

\section{Çalıșmanın Sınırlılıkları}

Tez çalışmalarının yürütüldüğü iller yapılan her tez çalışmasında açıkça belirtilmediği için, tezlerin ait oldukları iller "bölgeler"' başlığı altında gruplandırılmıştır. Ayrıca tezlerin yayın olma durumlarında arama hem Türkçe hem de İngilizce olarak yapılsa da, yayının başlığının tez çalışması başlığından farklı bir başlığa sahip olabilmesi veya kadın araştırmacıların soyadlarının evlilik durumunda değişebilmesi gibi nedenlere bağl1 olarak bazı tezlerin dergilerdeki yayınlarına ulaşılmasında yaşanan güçlükler de araştırmanın sınırlılığını oluşturmaktadır.
Araștırmanın Etik Yönü/ Ethics Committee Approval: Araştırmanın verileri YÖKTEZ'in sayfasından elde edilmiştir. Ayrıca literatür incelemesi yapılarak atıf yapılan yayınlar kaynaklar bölümünde gösterilmiştir. Etik soruna yol açacak herhangi bir unsur bulunmamaktadır.

Hakem/Peer-review: Dış hakem değerlendirmesi.

Yazar Katkısı/Author Contributions: Fikir/kavram: MÖ, NK; Tasarım: MÖ, NK; Kaynak tarama: MÖ, NK; Verilerin İşlenmesi: MÖ, NK: Analiz ve Yorum: MÖ, NK; Danışmanlık: NK; Eleştirel inceleme: NK.

Çıkar çatışması/Conflict of interest: $\mathrm{Bu}$ çalışmada herhangi bir çıkar çatışması bulunmamaktadır.

Finansal Destek/Financial Disclosure: $\mathrm{Bu}$ çalışmada herhangi bir kurum veya kuruluştan destek alınmamıştır.

\section{Calıșma Literatüre Ne Kattı?}

- İnfertilite alanında yapılmış olan lisansüstü tezlerinin genel özelliklerinin belirlenmesi,

- İnfertilite alanında hangi konuların sıklikla araştırıldığ 1 ve hangi gruplar üzerinde çalışıldı $\breve{g}$,

- Infertilite alanında, hemşirelik boyutunda, araştırılmaya ihtiyaç duyulan alanların belirlenmesine katkı sağlaması beklenmektedir.

\section{Kaynaklar}

Agarwal A, Mulgund A, Hamada A, Chyatte MR. (2015). A unique view on male infertility around the globe. Reproductive Biology and Endocrinology, 13, 37.e19.

Ahmadi H, Montaser Kouhsari L, Nowroozi MR, Bazargan Hejazi S. (2011). Male infertility and depression: a neglected problem in the Middle East. The Journal of Sexual Medicine, 8(3), 824-830.

Altamimi SI, Snobar RO, Al-Fraihat AA, Albuarki H, Rizk DEE. (2019). Causes of infertility. Bahrain Medical Bulletin, 41(2), 93-96.

Anokye R, Acheampong E, Mprah WK, Ope JO, Barivure TN. (2017). Psychosocial effects of infertility among couples attending St. Michael's Hospital, Jachie-Pramso in the Ashanti Region of Ghana. BMC Research Notes, 10, 690. e1-5.

Anwar S, Anwar A. (2016). Infertility: a Review on causes, treatment and management. Women's Health \& Gynecology, 2(6), 1-6.

Ardahan M, Özsoy S. (2015). Türkiye'de hemşirelik araştırmalarındaki eğilimler: Yüksek lisans ve doktora tezleri üzerine bir çalışma. Gümüşhane Üniversitesi Sağl1k Bilimleri Dergisi, 4(4), 516-534.

Bakhtiari A, Basirat Z, Nasiri-Amiri F. (2016). Sexual dysfunction in women undergoing fertility treatment in Iran: prevalence and associated risk factors. Journal of Reproductive \& Infertility, 17(1), 26-33. 
Boore JRP. (1996). Postgraduate education in nursing: a case study. Journal of Advanced Nursing, 23(3), 620629.

Brandes M, Van der Steen JO, Bokdam SB, Hamilton CJ, de Bruin JP, Nelen WL, ve ark. (2009). When and why do subfertile couples discontinue their fertility care? A longitudinal cohort study in a secondary care subfertility population. Human Reproduction, 24(12), 3127-3135.

Büyükkaya Besen D. (2016). Examining post graduate theses in nursing in Turkey between 1980-2015. The Journal of Health Services Research \& Policy, 1(2), 46-51.

Dağcı M, Baydur G, Kaynak K, Minigül L, Polat Ş. (2019). Türkiye'de 1991-2019 yılları arasında yapılan cerrahi hastalıkları hemșireliği lisansüstü tezleri. Ordu Üniversitesi Hemşirelik Çalıșmaları Dergisi, 2(3), 159-169.

Datta J, Palmer MJ, Tanton C, Gibson LJ, Jones KG, Macdowall W, ve ark. (2016). Prevalence of infertility and help seeking among 15000 women and men. Human Reproduction, 31(9), 2108-2118.

Dong YZ, Yang XX, Sun YP. (2013). Correlative analysis of social support with anxiety and depression in men undergoing in vitro fertilization embryo transfer for the first time. Journal of International Medical Research, 41(4), 1258-1265.

Ergöl, Ş. (2011). Türkiye'de yükseköğretimde hemşirelik eğitimi. Yükseköğretim ve Bilim Dergisi, 1(3), 152155 .

Gameiro S, van den Belt Dusebout AW, Bleiker E, Braat D, van Leeuwen FE, Verhaak CM. (2014). Do children make you happier? Sustained child-wish and mental health in women 11-17 years after fertility treatment. Human Reproduction, 29(10), 2238-2246.

Gao J, Zhang X, Su P, Liu J, Shi K, Hao Z, ve ark. (2013). Relationship between sexual dysfunction and psychological burden in men with infertility: a large observational study in China. The Journal of Sexual Medicine, 10(8), 1935-1942.

Goker A, Yanikkerem E, Birge O, Kuscu NK. (2018). Quality of life in Turkish infertile couples and related factors. Human Fertility, 21(3), 195-203.

Goli M, Ahmedi SM, Goli S. (2012). Irrational perception of parenthood in infertile women. Journal of Research in Behavioural Sciences, 10(324), 213-220.

Hocaoglu C. (2019). The Psychosocial Aspect of Infertility. Sheriff DS, editor. Infertility, Assisted Reproductive Technologies and Hormone Assays. London, UK: IntechOpen, s. 65-78.

Hollup O. (2014). The impact of gender, culture, and sexuality on Mauritian nursing: nursing as a nongendered occupational identity or masculine field? Qualitative study. International Journal of Nursing Studies, 51(5), 752-760.
Inhorn MC, Patrizio P. (2015). Infertility around the globe: new thinking on gender, reproductive technologies and global movements in the 21st century. Human Reproduction Update, 21(4), 411426.

Johnson KM, Greil AL, Shreffler KM, McQuillan J. (2018). Fertility and infertility: toward an integrative research agenda. Population Research and Policy Review, 37(5), 641-666.

Kjaer TK, Jensen A, Dalton SO, Johansen C, Schmiedel S, Kjaer SK. (2011). Suicide in Danish women evaluated for fertility problems. Human Reproduction, 26(9), 2401-2407.

Kroemeke A, Kubicka E. (2018). Positive and negative adjustment in couples undergoing infertility treatment: the impact of support exchange. PloS One, 13(6), e0200124.

Lakatos E, Szigeti JF, Ujma PP, Sexty R, Balog P. (2017). Anxiety and depression among infertile women: a cross-sectional survey from Hungary. BMC Women's Health, 17(1), 48.

Lotti F, Corona G, Castellini G, Maseroli E, Fino MG, Cozzolino M, ve ark. (2016). Semen quality impairment is associated with sexual dysfunction according to its severity. Human Reproduction, 31(12), 2668-2680.

Lotti F, Maggi M. (2018). Sexual dysfunction and male infertility. Nature Reviews Urology, 15(5), 287-307.

Luk BH, Loke AY. (2015). The impact of infertility on the psychological well-being, marital relationships, sexual relationships, and quality of life of couples: a systematic review. Journal of Sex \& Marital Therapy, 41(6), 610-625.

Maroufizadeh S, Ghaheri A, Almasi Hashian A, Mohammadi M, Navid B, Ezabadi Z, ve ark. (2017). The prevalence of anxiety and depression among people with infertility referring to Royan Institute in Tehran, Iran: a cross-sectional questionnaire study. Middle East Fertility Society Journal, 23(2), 103-106.

Makkizadeh F, Sa'adat F. (2017). Bibliometric and thematic analysis of articles in the field of infertility (2011-2015). International Journal of Reproductive BioMedicine, 15(11), 719-728.

Mascarenhas MN, Flaxman SR, Boerma T, Vanderpoel S, Stevens GA. (2012). National, regional, and global trends in infertility prevalence since 1990: a systematic analysis of 277 health surveys. PLoS Med, 9(12), e1001356.

Meadus RJ, Twomey JC. (2011). Men student nurses: the nursing education experience. Nursing Forum, 46(4), 269-279.

Mikkelsen AT, Madsen SA, Humaidan P. (2013). Psychological aspects of male fertility treatment. Journal of Advanced Nursing, 69(9), 1977-1986.

Obeidat HM, Hamlan AM, Callister LC. (2014). Missing motherhood: Jordanian women's experiences with infertility. Advances in Psychiatry, 1-7. 
O’Lynn C. (2013). A man's guide to a nursing career. New York: Springer Publishing Company.

Ombelet W. (2011). Global access to infertility care in developing countries: a case of human rights, equity and social justice. Facts, Views \& Vision Isssues in Obstetrics, Gynaecology and Reproductive Health, 3(4), 257-266.

Ozkan B, Orhan E, Aktas N, Coskuner ER. (2015). Depression and sexual dysfunction in Turkish men diagnosed with infertility. Urology, 85(6), 1389-1393.

Ozturk S, Sut Kahyaoglu H, Kucuk L. (2019). Examination of sexual functions and depressive symptoms among infertile and fertile women. Pakistan Journal of Medical Sciences, 35(5), 13551360.

Öncel S, Sümen A. (2017). Türkiye'de halk sağlığ1 hemşireliği alanında yürütülen lisansüstü tezlerin değerlendirilmesi. Türkiye Klinikleri Halk Sağlığ Hemşireliği-Özel Konular, 3(1), 20-28.

Punab M, (2017). Causes of male infertility: a 9-year prospective monocentre study on 1737 patients with reduced total sperm counts. Human Reproduction, 32(1), 18-31.

Sathiyanarayanan S, Sundar JS, Madhankumar EK, Praneetha A, Kalaiselvi S, Gopinath PM, ve ark. (2014). A study on significant biochemical changes in the serum of infertile women. International Journal of Current Research and Academic Reviiew, 2(2), 96115 .

Sezgin H, Hocaoglu C. (2014). Psychiatric aspects of infertility. Current Approaches in Psychiatry, 6(2), 165-184.

Shin J, Lee SG, Park EC, Nam JY. (2020). Socioeconomic status and successful delivery after an infertility diagnosis: a nationwide health insurance cohort study in Korea conducted from 2005 to 2013. Journal of Korean Medical Science, 35(39), e341.
Sis Çelik A, Kırca N. (2018). Primer inferil kadınların infertiltieye bağlı yaşadıkları stres düzeyleri ve etkileyen bazı faktörlerin belirlenmesi. Anadolu Hemşirelik ve SağlıkBilimleri Dergisi, 21(2), 104114.

Smith JS. (2006). Exploring the challenges for nontraditional male students transitioning into a nursing program. The Journal of Nursing Education, 45(7), 263-267.

Szreter, S. (1993). The idea of demographic transition and the study of fertility change: a critical intellectual history. Population and Development Review, 19(4), 659-701.

World Health Organization (WHO). (2011). World report on disability. Erişim tarihi: 16.11.2020, https://www.who.int/disabilities/world_report/2011/r eport.pdf

Yang B, Zhang J, Qi Y, Wang P, Jiang R, Li H. (2017). Assessment on occurrences of depression and anxiety and associated risk factors in the infertile Chinese men. American Journal of Men's Health, 11(3), 767774.

Yılmaz A, Yazgan EÖ, Dur B, Salman F, Demir A. (2017). Türkiye'de hemşirelik lisansüstü tezlerinin yayın olma durumu: Bibliyometrik Çalışma (19772016). Hemşirelikte Araştırma Geliştirme Dergisi, 19(3), 34-44.

Yüksel Koçak D, Büyükkayacı Duman N. (2019). Türkiye'de hemşirelik alanında üreme sağlı̆̆ sağlı konularında yapılmış olan tezlerin içerik açısından incelenmesi. Acıbadem Üniversitesi Sağlık Bilimleri Dergisi, 10(2), 265-270.

Zegers-Hochschild F, Adamson GD, Dyer S, Racowsky C, de Mouzon J, Sokol R, ve ark. (2017). The international glossary on infertility and fertility care, 2017. Fertility and Sterility, 108(3), 393-406. 